\title{
STANDARDS PROBATÓRIOS NO CONTEXTO DA RESPONSABILIDADE CIVIL DO MÉDICO ${ }^{1}$
}

\section{STANDARDS OF PROOF IN THE CONTEXT OF THE MEDICAL CIVIL RESPONSIBILITY}

Clarissa Diniz Guedes

Doutora em Direito Processual pela Universidade de São Paulo - (USP); Mestre em Direito Processual pela Universidade do Estado do Rio de Janeiro - (UERJ). Juiz de Fora, Minas Gerais, Brasil. Vinculada à instituição Universidade Federal de Juiz de Fora (UFJF). Professora Adjunta da Universidade Federal de Juiz de Fora/UFJF. clarissadinizguedes@gmail.com

Laís Almeida de Souza Lopes Mestranda em Direito e Inovação pela Universidade Federal de Juiz de Fora - (UFJF). Pós - Graduanda em Direito Processual pela Pontifícia Universidade Católica de Minas Gerais - (PUC Minas). Governador Valadares, Minas Gerais, Brasil. Vinculada à instituição Universidade Federal de Juiz de Fora - (UFJF). laislopess25@gmail.com

RESUMO: O presente estudo problematiza os standards probatórios ou modelos de constatação no contexto da responsabilidade civil do médico, tendo por objetivo central verificar, a partir de percepção doutrinária e estudo de casos extraídos, qual seria o grau de suficiência de prova exigível para comprovar a culpa nas ações de responsabilidade civil por erro médico. Adotou-se como referencial teórico a persuasão racional. A pesquisa demonstrou que o paciente demandante deve provar a culpa por meio do standard da prova

\footnotetext{
${ }^{1}$ Artigo recebido em 10/07/2017 e aprovado em 04/08/2017.
} 
Revista Eletrônica de Direito Processual - REDP.

Rio de Janeiro. Ano 11. Volume 18. Número 2. Maio a Agosto de 2017

Periódico Quadrimestral da Pós-Graduação Stricto Sensu em Direito Processual da UERJ

Patrono: José Carlos Barbosa Moreira. ISSN 1982-7636. pp. 88-115

www.redp.uerj.br

clara e convincente. Já o médico, em eventual flexibilização do ônus de prova, deve demonstrar a ausência de sua culpa por meio de um standard de grau mínimo.

PALAVRAS-CHAVE: standards probatórios, responsabilidade civil do médico, prova, persuasão racional.

ABSTRACT: This paper discusses the standards of proof, also known as sufficiency models, in the context of the medical civil responsibility. The purpose of this study is to verify, from a doctrinal perception and from a study of cases, what would be the standard required to prove the fault in medical civil responsibility due to medical error. Rational persuasion was adopted as theoretical reference. We came to the conclusion that the patient, who is the plaintiff, shall prove the medical fault through a high standard of proof: the clear and convincing evidence. Nevertheless, if occurs a dynamic distribution of the burden of proof, the doctor shall demonstrate absence of medical fault through a low level standard of proof.

KEYWORDS: standards of proof, medical civil responsibility, proof, rational persuasion.

SUMÁRIO: Introdução. 2. A racionalidade do discurso jurídico processual. 2.1. Prova e persuasão racional. 2.2. Guias de valoração racional para controle do juízo de fato. 3. Breves considerações acerca da responsabilidade civil do médico. 3.1 A prova da culpa do médico sob a ótica dos standards probatórios. 4. Conclusão. Referências bibliográficas.

\section{Introdução}

Não mais se pode reputar como racionalmente aceitável em um Estado Democrático de Direito que o julgador, utilizando-se do livre convencimento motivado, faça a valoração das provas e decida a causa simplesmente justificando os motivos de fato e de direito que o levaram a decidir dessa forma, sem haver clareza sobre os critérios 
Revista Eletrônica de Direito Processual - REDP.

Rio de Janeiro. Ano 11. Volume 18. Número 2. Maio a Agosto de 2017

Periódico Quadrimestral da Pós-Graduação Stricto Sensu em Direito Processual da UERJ

Patrono: José Carlos Barbosa Moreira. ISSN 1982-7636. pp. 88-115

www.redp.uerj.br

utilizados. É preciso submeter a "livre" convicção à análise de sua estrutura lógica, possibilitando-se o debate sobre a razoabilidade, acerto e coerência do juízo fático.

Isso pode ser feito a partir dos standards de prova, também conhecidos como modelos de constatação ou guias de valoração racional, que funcionam como parâmetros lógico-racionais que têm por finalidade não apenas orientar os julgadores a respeito do grau de suficiência de prova exigível para se confirmar racionalmente determinada hipótese fática, como também propiciar o controle do juízo de fato.

Convém frisar que a adoção dos modelos de constatação ou standards de prova não afasta o objetivo de busca da verdade, inerente tanto ao processo civil quanto ao processo penal. Porém, a falibilidade humana conduz à necessidade de se regular o chamado núcleo débil da epistemologia jurídica ${ }^{3}$, que cuida de distribuir os riscos de erro quando já não é possível minorá-los.

Como esses critérios são determinados por fatores de ordem jurídica, política e até moral, não é possível identificar plenamente, de um lado, a suficiência probatória para demonstração de um fato na perspectiva de determinado standard probatório, com, de outro, a suficiência probatória do ponto de vista epistemológico. ${ }^{4}$ Sob esta ótica, os modelos de constatação incidem como limitações ao julgamento dos fatos, impondo barreiras à delimitação do resultado probatório conforme o contexto em que se encontrem e os valores que norteiam cada relação processual. É nessa perspectiva que se desenvolve o presente estudo. Assim sendo, adotamos como tema os chamados standards probatórios, os quais serão analisados e problematizados no contexto das ações de responsabilidade civil do médico.

\footnotetext{
${ }^{2}$ Conforme adiante se argumentará, o significado atual da expressão, mais corretamente designada como "persuasão racional", não se confunde com a liberdade irrestrita de convencimento verificada nos sistemas de íntima convicção. V., nesse sentido: GUEDES, Clarissa Diniz. Persuasão racional e limitações probatórias: enfoque comparativo entre os processos civil e penal. Tese de doutorado, orientador: José Rogério Cruz e Tucci. São Paulo: USP, 2013, pp. 170 e ss., em que se destaca que a dicotomia entre os sistemas de livre convencimento e de provas legais é simplista, havendo gradações daquele.

3 LAUDAN, Larry. Por qué un estándar de prueba subjetivo y ambiguo no es un estándar. DOXA, Cuadernos de Filosofía del Derecho, 28 (2005), p. 96., pp. 96-97.

${ }^{4}$ Consoante posicionamento recentemente expressado por Jordi Ferrer Beltrán: "Efetivamente, a decisão sobre o nível de suficiência probatória não é, em absoluto, epistemológica. A epistemologia pode auxiliar-nos a delinear um standard de prova que reflita corretamente o nível de suficiência probatória que se decidiu adotar, mas nada nos diz sobre o próprio nível. É uma decisão política”.(A prova é liberdade, mas não tanto: uma teoria da prova quase-benthamaniana. In: DIDIER JR., Fredie (coord); MACÊDO, Lucas Buril de; PEIXOTO, Ravi; FREIRE, Alexandre. Provas. Coleção novo CPC. Doutrina selecionada. Salvador: Jus Podivm, 2016, pp. 103-122, especificamente p. 113).
} 
Revista Eletrônica de Direito Processual - REDP.

Rio de Janeiro. Ano 11. Volume 18. Número 2. Maio a Agosto de 2017

Periódico Quadrimestral da Pós-Graduação Stricto Sensu em Direito Processual da UERJ

Patrono: José Carlos Barbosa Moreira. ISSN 1982-7636. pp. 88-115

www.redp.uerj.br

Buscamos como objetivo geral, verificar, a partir da análise doutrinária e estudo de

casos, qual seria o standard probatório ou grau de constatação de prova exigível para se aferir a culpa nas ações de responsabilidade civil por erro médico. Temos como objetivos específicos: explorar o conceito e as espécies de standards de prova; compreender finalidade desses modelos de constatação diante do sistema de persuasão racional; verificar analisar as questões éticas, políticas e morais subjacentes à escolha de determinado standard, especificamente no que tange às ações de responsabilidade civil por erro médico.

Considerando o referencial teórico da persuasão racional, compreendida como a liberdade relativa de valoração probatória, realizada dentro de parâmetros lógico-racionais entre os quais se incluem os standards probatórios, afirma-se, como hipótese desta pesquisa, que o grau de constatação/standard para aferição da culpa médica não é o da prova prevalente, mas sim o da prova clara e convincente de que o médico não agiu conforme a diligência esperada de um profissional sob as mesmas circunstâncias.

Quanto à metodologia, a confirmação dessa hipótese será feita mediante análise doutrinária e estudo de casos, os quais serão extraídos da jurisprudência do TJRS. A opção por uma pesquisa qualitativa a partir da análise de casos específicos advém do fato de serem os standards probatórios uma construção eminentemente jurisprudencial, de caráter não generalizável indistintamente a todos os tipos de processo, mas desenvolvidos a partir das particularidades de cada relação jurídica e bens jurídicos envolvidos.

Os julgados utilizados no estudo de casos desse artigo foram selecionados manualmente a partir dos resultados $\operatorname{obtidos}^{5}$ da pesquisa jurisprudencial feita na plataforma online do TJRS. ${ }^{6}$ Com a finalidade de atender aos objetivos do presente estudo, procedeu-se à utilização separada de dois conjuntos de expressões de busca, a saber: “responsabilidade civil e erro médico e prova e culpa não responsabilidade médica hospitalar" e "responsabilidade civil e erro médico e inversão do ônus não

\footnotetext{
${ }^{5}$ Ao todo foram obtidos 154 resultados, todos lidos e analisados pelas pesquisadoras. A amostra submetida ao estudo de casos corresponde ao entendimento predominante (uníssono) do Tribunal verificado nesse grupo de acórdãos, tendo sido 4 o número de julgados selecionados para realização do estudo de casos desse artigo. ${ }^{6}$ Ressalte-se, nesse iter, uma importante limitação metodológica quando à pesquisa quantitativa: a tentativa de pesquisa jurisprudencial em diversos tribunais da federação a partir das palavras de busca "standard", "padrão de constatação" ou "modelo de confirmação", as quais eventualmente poderiam propiciar uma robusta pesquisa exploratória, trouxe, na verdade, resultados escassos e/ou impertinentes ao tema, e a inserção conjunta dessas palavras com as expressões "responsabilidade civil do médico e erro médico ora diminuiu (quando a opção assinalada se referia à obrigatoriedade de ' todas as expressões') ora aumentou excessivamente os resultados (quando fosse facultativa a verificação de uma ou de outra expressão, v.g., "standards" ou "erro médico") inviabilizando, no último caso, a análise de todos os julgados.
} 
Revista Eletrônica de Direito Processual - REDP.

Rio de Janeiro. Ano 11. Volume 18. Número 2. Maio a Agosto de 2017

Periódico Quadrimestral da Pós-Graduação Stricto Sensu em Direito Processual da UERJ

Patrono: José Carlos Barbosa Moreira. ISSN 1982-7636. pp. 88-115

www.redp.uerj.br

responsabilidade médica hospitalar', ambos delimitados ao período de 01/01/2014 a

01/12/2016. O conectivo "não" funcionou como única solução para reduzir o número de registros impertinentes.

\section{A racionalidade do discurso jurídico processual}

\subsection{Prova e persuasão racional}

A respeito do tratamento dispensado ao tema da prova pela ciência do direito, Michele Taruffo censura os juristas por se dedicarem excessivamente às normas positivas que regulam a admissibilidade, a produção e a valoração da prova, de tal maneira que "quando os juristas decidem encarar os problemas filosóficos da prova demonstram ser péssimos filósofos, obtendo resultados modestos e risíveis., "7__

Conforme demonstra Danilo Knijnik, ${ }^{9}$ esse déficit teórico pode ser explicado a partir de alguns argumentos. Primeiramente, o caráter refratário da prova judiciária, o qual dificulta abordagens eminentemente jurídicas em virtude da resistência quanto à inserção do juízo de fato em estruturas legais, havendo uma tendência à sua inserção no campo da lógica, epistemologia e psicologia. Em segundo lugar, destaca o autor, há um perigoso subjetivismo imposto pelo princípio do livre convencimento motivado, pois existe uma natural tendência de a abordagem do direito probatório voltar-se para o campo da interpretação e do subjetivismo, desvalorizando, por conseguinte, o aspecto normativo da teoria da prova judicial.

O livre convencimento motivado ou livre persuasão racional não constitui uma "carta branca" dirigida ao magistrado para admitir ou deixar de admitir quaisquer meios de prova,${ }^{10}$ e, sequer, para valorar os elementos probatórios como bem entender ${ }^{11}$. Para a

\footnotetext{
7 TARUFFO, Michele. Prólogo da obra do autor Jordi Ferrer Beltrán: Prueba y verdade em el derecho. 2 edición. Barcelona: Marcial Pons, 2005, p. 11-12.

8 “Assim, por exemplo, na literatura processualista como também na filosofia permanece o mistério do significado de expressões como, por exemplo, 'o direito está provado', embora obviamente seja uma questão fundamental em qualquer processo, sobre esse ponto se encontram frequentemente respostas vagas e genéricas. Alguns autores fazem referência, quase sempre, de forma superficial à probabilidade ou verossimilhança, mas, sobre o significado dessas expressões, normalmente permanece a incerteza." (TARUFFO, Michele. Idem ibidem).

${ }^{9}$ KNIJNIK, Danilo. A prova nos juízos cível, penal e tributário. Rio de Janeiro: Forense, 2007, p. 5-6.

${ }^{10}$ Cf., a propósito: GUEDES, Clarissa Diniz; LEAL, Stela Tannure. O cerceamento do acesso à prova devido à confusão entre os planos de admissibilidade e valoração do material probatório. Revista de Processo, v. 240, p. 15-40, fev. 2015; DEMARI, Lisandra. Juízo de relevância da prova. In: KNIJNIK, Danilo (coord.) Prova Judiciária. Estudos sobre o novo direito probatório. Porto Alegre: Livraria do Advogado, 2007, pp. 171 e ss.; MATTOS, Sérgio. O juiz é destinatário da prova: porta aberta para o arbítrio? In: MITIDIERO,
} 
Revista Eletrônica de Direito Processual - REDP.

Rio de Janeiro. Ano 11. Volume 18. Número 2. Maio a Agosto de 2017

Periódico Quadrimestral da Pós-Graduação Stricto Sensu em Direito Processual da UERJ

Patrono: José Carlos Barbosa Moreira. ISSN 1982-7636. pp. 88-115

www.redp.uerj.br

satisfação desse princípio não é suficiente a fundamentação da conclusão do juiz, mas, antes, é preciso que se observem parâmetros lógicos. A liberdade de que ora se trata é, pois, uma liberdade objetiva, dirigida à razão prática, à lógica do discurso e à teoria da argumentação. $^{12}$

Para que se possa valorar a prova a partir de critérios racionais e lógicos - o que é imprescindível num Estado Democrático de Direito -, é preciso superar a compreensão negativa do livre convencimento, que é aquela que se contrapõe à predeterminação valorativa das provas legais, e buscar uma definição mais clara do sistema, no sentido positivo $^{13}$.

Santiago Sentis Melendo ${ }^{14}$ esclarece que o livre convencimento abrange a chamada "sana critica", sistema equiparado ao da livre persuasão racional por Carlo Lessona, conhecido do ordenamento espanhol e de alguns países de origem latina que sofreram influência hispânica. Esta - a "sana critica" - seria um desmembramento do livre convencimento, uma das formas pelas quais ele se manifesta. ${ }^{15}$

A ideia de persuasão racional está muito relacionada à valoração das provas produzidas nos autos; bem como às regras lógicas e racionais pelas quais o juiz se deve orientar nessa valoração. ${ }^{16 \_}{ }^{17} \mathrm{O}$ que se há de ponderar é que as regras jurídicas, lógicas e

Daniel e AMARAL, Guilherme Rizzo (Coord). Processo civil. Estudos em homenagem a Carlos Alberto Alvaro de Oliveira. São Paulo: Atlas, 2012, pp. 447-458.

11 DIDIER JR., Fredie; BRAGA, Paula Sarno; OLIVEIRA, Rafael Alexandria de. Curso de Direito Processual Civil: teoria da prova, direito probatório, ações probatórias, decisão, precedente, coisa julgada e antecipação dos efeitos da tutela. V. 2. 10ª ed. Salvador: Jus Podivm, 2015, p. 102.

12 KNIJNIK, Danilo. Os Standards do Convencimento Judicial: paradigmas para o seu possível controle. Disponível em: 〈http://www.abdpc.org.br/abdpc> acesso em: 01/04/ 2017, p. 21.

${ }^{13}$ Clamam pela necessidade de se compreender o sentido positivo do livre convencimento, entre outros: NOBILI, Massimo. Il principio del libero convincimento del giudice. Milano: Giuffrè, 1974, p. 9 e passim; PATTI, Salvatore. Libero Convincimento e valutazione delle prove, Rivista di diritto processuale. Ano XL, n. 3. Padova: CEDAM, 1985, p. 481-519, especialmente p. 482; Michele Taruffo, em apresentação à seguinte obra: FERRER BELTRAN, Jordi. Prova e verità nel diritto, Bologna: Società editrice il Mulino, 2004, p. 7 e no prólogo de NIEVA FENOLL, Jordi. La valoración de la prueba, Madrid/Barcelona/Buenos Aires: Marcial Pons, 2010, p. 15.

${ }^{14}$ SENTÍS MELENDO, Santiago. La prueba. Buenos Aires: EJEA, 1978, p. 268.

${ }^{15}$ Sobre a persuasão racional, explica Carlo Lessona: "O juiz deve pesar com justo critério lógico o valor dos elementos de prova, e somente pode ter como verdadeiro o fato controvertido com base em provas que excluam toda a dúvida em contrário. A verdade jurídica depende, neste sistema, não da impressão, mas da consciência do juiz que não pode julgar simplesmente por seu critério individual, mas de acordo com as regras da verdade histórica, que deve fundamentar." (Teoría general de prueba en derecho civil o exposición comparada de los principios de la prueba y sus diversas aplicaciones en Italia, Francia, Alemana etc., Madrid: Instituto Editorial Réus, 1957, p. 355, n. 328 bis) - tradução livre.

16 Nesse sentido, exemplificativamente: CORDERO, Franco, In: Tre studi sulle prove penali. Milano: Giuffrè, 1963, §5, pp. 26-27; PATTI, Salvatore. Libero convincimento e valutazione delle prove, Rivista di Diritto Processuale. Ano XL, n. 3. Padova: CEDAM, 1985, p. 486 e passim; SENTÍS MELENDO, Santiago. 
Revista Eletrônica de Direito Processual - REDP.

Rio de Janeiro. Ano 11. Volume 18. Número 2. Maio a Agosto de 2017

Periódico Quadrimestral da Pós-Graduação Stricto Sensu em Direito Processual da UERJ

Patrono: José Carlos Barbosa Moreira. ISSN 1982-7636. pp. 88-115

www.redp.uerj.br

da experiência a que o juiz está sujeito não são regras legais - e, muito menos, regras legais inflexíveis - que ditem previamente o valor das provas. ${ }^{18}$

Deve-se pontuar que a persuasão racional observa certas diretrizes gerais a fim de se prevenir o arbítrio: o juiz deve se ater aos fatos debatidos, deve utilizar apenas os conhecimentos fáticos processualmente adquiridos, sendo vedada a utilização da ciência privada, deve levar em consideração todo o material probatório (ou seja, todos os elementos de prova) e todo o conhecimento extraído processualmente e deve, por fim, motivar seu convencimento. ${ }^{19}$

Além disso, e antes mesmo da motivação, tendo em vista a consideração inicialmente feita sobre a amplitude da expressão livre convencimento, deve o juiz ter presente, no momento de decidir, após valorados os elementos probatórios, a gradação da prova considerada suficiente para decidir, conforme o grau ou modelo de constatação necessário à formação do convencimento em cada matéria específica.

Se a persuasão racional, inserida que está no sistema do livre convencimento - pois não há racionalidade sem liberdade -, refuta, por um lado, as limitações peremptoriamente impostas à valoração da prova, busca, por outro, impor limitações racionais e flexíveis ao

La prueba. Buenos Aires, Ediciones Juridicas Europa-America, 1978, p. 268, SILVA MELERO, Valentín, La prueba procesal. Teoría general. Madrid: Editorial Revista de Derecho Privado, 1963, Primeira Parte, Capítulo IV, item II, p. 127.

${ }^{17}$ Nessa linha, Moacyr Amaral Santos observa que, no sistema da persuasão ou convicção racional: "O juiz, não obstante aprecie as provas livremente, não segue as suas impressões pessoais, mas tira a sua convicção das provas produzidas, ponderando sobre a qualidade e vis probandi destas; a convicção está na consciência formada pelas provas, não arbitrária e sem peias, e sim condicionada a regras jurídicas, a regras da lógica, a regras de experiência, tanto que o juiz deve mencionar na sentença os motivos que a formaram. A liberdade que se concede ao juiz não é um mero arbítrio, senão um critério de atuação ajustado aos deveres profissionais. Há liberdade no sentido de que o juiz aprecie as provas livremente, uma vez que a apreciação não se afaste dos fatos estabelecidos, das provas colhidas, das regras científicas - regras jurídicas, regras da lógica, regras da experiência." (Prova Judiciária no Cível e no Comercial. V. 1, $5^{\text {a }}$ ed. São Paulo: Saraiva, 1983, Capítulo XVIII, item 244, pp. 398-399).

18 Interessante transcrever aqui a explicação de Michele Taruffo: "Falar de critérios para uma eleição racional da hipótese fática, que se reconheça como 'verdadeira' por ser a mais aceitável com base na prova dos autos, não significa, portanto, fazer referência a regras precisas e estritamente obrigatórias, senão a standards capazes de orientar as eleições e determiná-las. A eleição da 'melhor' alternativa, por ser mais racional, não está completamente predeterminada nem é inteiramente livre. Não é cálculo nem arbítrio. Pode ser, ao contrário, razoável se a valoração leva em conta a análise das situações probatórias e da forma que nelas se configura a relação inferencial entre elementos de prova e hipóteses fáticas, assim como se a eleição final se realiza, de sua vez, com base em parâmetros que partem daquela relação. $\mathrm{Na}$ realidade, a discricionariedade das valorações e das eleições pode não equivaler a uma irredutível vagueza ou incerteza da decisão e a liberdade da convicção pode ser guiada por critérios racionais'. (La prueba de los hechos. Traducción de Jordi Ferrer Beltrán. Madrid: Editorial Trotta, 2002, Capítulo IV item 4, pp. 294-295. Tradução livre).

19 DOSI, Ettore. Sul principio del libero convincimento del giudice nel processo penale. Milano: Giuffrè, 1957, Terceira Parte, III, p. 69. 
Revista Eletrônica de Direito Processual - REDP.

Rio de Janeiro. Ano 11. Volume 18. Número 2. Maio a Agosto de 2017

Periódico Quadrimestral da Pós-Graduação Stricto Sensu em Direito Processual da UERJ

Patrono: José Carlos Barbosa Moreira. ISSN 1982-7636. pp. 88-115

www.redp.uerj.br

arbítrio, nas quais se inserem as regras que estabelecem critérios para julgamento (v.g., fixação de ônus e previsão de standards probatórios). ${ }^{20}$

Verifica-se, pois, que a preocupação contemporânea com a racionalidade das decisões sobre questões fáticas volta-se à adoção de parâmetros adequados também para a tomada de decisão. E tais parâmetros serão variáveis para as diversas espécies de processo, assim como são variáveis os contextos políticos e jurídicos que os determinam.

Nessa perspectiva, a prova no direito processual contemporâneo é compreendida como argumento, ordenado segundo normas ético-jurídicas e lógico-argumentativas, empregado no sentido de persuadir racionalmente o juiz, possibilitando a apreensão da realidade histórica considerada juridicamente relevante. ${ }^{21}$ Cumpre ressaltar, todavia, que, na visão das autoras desse artigo, a dimensão argumentativa não exclui o caráter demonstrativo da prova, cujo objetivo principal constitui a busca da verdade, num sentido aproximativo. $^{22}$

Com efeito, ressalta Danilo Knijnik que não é possível compreender a relação entre prova e verdade sem que se considere a polaridade assimétrica dos institutos do direito probatório, que ora pendem para uma concepção demonstrativa ora para uma concepção persuasiva de prova. A concepção persuasiva enfatiza a consciência da chance de erro na reconstrução dos fatos, enquanto a demonstrativa, a busca pelo alcance máximo da verdade dos fatos, de modo que esses dois modelos se completam durante a atividade probatória. ${ }^{23}$

\footnotetext{
${ }^{20}$ As regras que limitam a admissibilidade, as formas de produção e de valoração da prova traduzem vínculos que operam, por assim dizer, in itinere, porquanto orientam ou limitam o convencimento do juiz no ato da elaboração dos resultados de prova. Por outro lado, as regras de julgamento ganham relevo na fase final do procedimento decisório, quando se trata de confrontar os resultados probatórios adquiridos com a argumentação das partes e de tomar uma decisão sobre os fatos (MONICA, Giuseppe Della. La parabola del libero convincimento. In: GAITO, Alfredo. La prova penale. Volume Terzo (La valutazione della prova). Torino: UTET Giuridica, 2008, Capítulo XLVIII, Seção III, item 8, p. 322).

${ }^{21}$ REICHELT, Luis Alberto. A Prova no Direito Processual Civil. Porto Alegre: Livraria do Advogado, 2009, p. 111.

${ }^{22}$ Cf., nesse sentido: TARUFFO, Michele. La prueba de los hechos, op. cit., capítulo III, item 1, pp. 178-180; GRECO, Leonardo. O conceito de prova. Estudos de Direito Processual. Campos dos Goytacazes: Editora da Faculdade de Campos, 2005, pp. 428 e ss.; GUZMÁN, Nicolás. La verdad en el proceso penal. Una contribución a la epistemología jurídica, Buenos Aires: Editores del Puerto, 2006, pp. 98-99; FERRAJOLI, Luigi. Direito e Razão. Teoria do Garantismo Penal. $4^{\mathrm{a}}$ ed. rev. Trad. de Ana Paula Zomer Sica e outros. São Paulo: RT, 2014, Primeira Parte, Cap. I, 4, p. 55.

${ }^{23}$ KNIJNIK, Danilo. A prova nos juízos cível, penal e tributário. Rio de Janeiro: Forense, 2007, pp.10 e 15.
} 
Revista Eletrônica de Direito Processual - REDP.

Rio de Janeiro. Ano 11. Volume 18. Número 2. Maio a Agosto de 2017

Periódico Quadrimestral da Pós-Graduação Stricto Sensu em Direito Processual da UERJ

Patrono: José Carlos Barbosa Moreira. ISSN 1982-7636. pp. 88-115

www.redp.uerj.br

Por meio desse raciocínio, chega-se à conclusão de que existe uma relação teleológica entre prova e verdade. ${ }^{24} \mathrm{O}$ sistema deve pautar-se pelo objetivo do descobrimento máximo da verdade, mas o juiz deve ter em mente que a verdade buscada no processo deve ser uma verdade relativa, como todas as verdades. ${ }^{25}$

\subsection{Standards probatórios como guias de valoração racional para o controle do juízo de fato}

A racionalidade do discurso jurídico processual pressupõe um controle jurídico da formação do juízo de fato e, por conseguinte, da convicção judicial objeto de uma determinada decisão. ${ }^{26}$ Contudo, a visão positivista do processo judicial, pautada no silogismo jurídico e na separação da análise do fato e do direito ${ }^{27}$ ainda não foi totalmente superada pela prática brasileira. Isso se torna evidente a partir do instante em que percebemos que as decisões judiciais brasileiras não explicitam, em regra, os esquemas racionais de valoração de provas. ${ }^{28}$

A esse respeito, Vittorio Denti traz à tona duas relevantes opções teóricas: ou se exclui a possibilidade mesma de um controle puramente lógico do juízo de fato, resolvendo-se tal controle na mera renovação do próprio juízo ou se recorre a parâmetros lógicos, partindo-se da premissa de que a racionalidade do convencimento do juiz sobre o direito está dada pelo valor da probabilidade sobre a qual se funda a inferência probatória. $^{29}$

24 FERRER BELTRÁN, Jordi. La valoración racional da la prueba. Madrid/Barcelona/Buenos Aires: Marcial Pons, 2007, introdução, p. 20. V., entre nós, no mesmo sentido: ALVIM NETTO, José Manoel de Arruda. Manual de direito processual civil. $17^{\text {a }}$ ed. São Paulo: RT, 2017, p. 854.

${ }^{25}$ TARUFFO, Michele. La prova dei fatti giuridici. Milano: Giuffrè 1992, p. 8 e ss.

${ }^{26}$ REICHELT, Luis Alberto. A Prova no Direito Processual Civil, op. cit., p.187.

${ }^{27}$ MARINONI, Luiz Guilherme; ARENHART, Sérgio Cruz; MITIDIERO, Daniel. Novo curso de processo civil: teoria do processo civil. V.1. São Paulo: RT, 2015, pp. 36 a 38. A respeito do positivismo abordado nesse trabalho, ver: Hans Kelsen. Teoria Pura do Direito. [tradução João Baptista Machado]. $6^{a}$ ed. São Paulo: Martins Fontes, 1998.

${ }^{28}$ No Brasil, os julgadores não têm o costume de enunciar aprioristicamente qual será o standard de prova a ser utilizado na formação do juízo de fato, atitude que impede uma efetiva submissão do raciocínio judicial ao contraditório objetivo. A explicitação prévia dos critérios de decisão pode ser entendida não somente como questão de ordem política como também de direito. Ora, o julgador atua em representação da administração da justiça toda, de maneira que a sua decisão deve ser objetivamente motivada a fim de ter o condão de ser considerada justa por qualquer outro sentenciador. Ademais, é questão de direito por influenciar decisivamente no resultado da decisão final. (KNIJNIK, Danilo. A prova nos juízos cível, penal e tributário, op. cit., pp. 32-33).

${ }^{29}$ DENTI, Vittorio. Cientificidad de la prueba y libre valoración del juez. Estudios de derecho probatorio. Tradução para o castelhano de Santiago Sentís Melendo e Tomás A. Banzhaf. Buenos Aires: EJEA, 1974, p. 296-297. 
Revista Eletrônica de Direito Processual - REDP.

Rio de Janeiro. Ano 11. Volume 18. Número 2. Maio a Agosto de 2017

Periódico Quadrimestral da Pós-Graduação Stricto Sensu em Direito Processual da UERJ

Patrono: José Carlos Barbosa Moreira. ISSN 1982-7636. pp. 88-115

www.redp.uerj.br

Ao adotarmos a segunda opção, sugerimos o estabelecimento de modelos de valoração da prova, ou seja, guias de valoração racional para o controle do juízo de fato. Por meio de tais modelos de constatação ou standards de prova, torna-se possível estabelecer um complexo de regras lógicas de caráter auxiliar capazes de estabelecer um espaço crítico comum para o debate acerca da convicção. É nesse contexto que adotamos a teoria dos "standards of proof", também chamados de "modelos de constatação" ou “standards probatórios", a qual surgiu ao longo da prática jurídica de Common Law ${ }^{30}$, não sendo, porém, desconhecida pelos sistemas de Civil Law. ${ }^{31}$

Os modelos de constatação podem ser inicialmente conceituados como "critérios para efetivamente submeter ao contraditório, a par de um diálogo comum, as opções valorativas do juiz', ${ }^{32}$ Segundo já entendeu a Suprema Corte norte-americana em decisão paradigmática $^{33}$ trata-se da tentativa de instruir o juiz acerca do grau de confiança que a sociedade acredita que ele deveria ter no momento de aferir a veracidade de suas conclusões factuais. Para Jordi Ferrer Beltrán, a utilização dos standards permite "dispor de uma teoria que nos diga quando, ou sob que condições, os elementos de juízo disponíveis são suficientes para que se repute racional aceitar uma proposição como verdadeira no âmbito do raciocínio decisório".34

Quando determinado standard probatório é estabelecido, o juiz não pode mais considerar a alegação de determinado fato como provada se não for atingido um grau de convencimento mínimo exigido por esse standard. Caso isso ocorra, o julgador deverá

30 REICHELT, Luis Alberto. A Prova no Direito Processual Civil, op. cit., p. 216. Sobre o tema, especificamente no processo penal, v., ainda, BADARÓ, Gustavo. Processo penal. $3^{\mathrm{a}}$ ed. São Paulo: RT, 2015, pp. 431 e ss.

31 Essa falta de maior interesse da doutrina processual penal brasileira em aprofundar os estudos dos standards de prova foi expressamente afirmada por Gustavo Badaró: "o tema dos critérios de decisão tem sido muito pouco explorado pela doutrina processual brasileira, que geralmente se limita a apreciar a questão sob o enfoque do in dubio pro reo, mas não dos diversos graus que se pode exigir do julgador para que considere um fato 'provado' ou mesmo para que se tenha como satisfeito um requisito legal de 'mera probabilidade' e não de 'certeza', (Processo Penal. Rio de Janeiro: Campus: Elsevier, 2012, p. 298).

${ }^{32}$ KNIJNIK, Danilo. Op. cit., p. 21.

${ }^{33}$ UNITED STATES SUPREME COURT. In re Winship. No. 778. Decided: March 31, 1970: Rena K. Uviller for appellant and Stanley Buchsbaum for appellee. Mr. Justice Brennan delivered the opinion of the court. No original: "In this regard, a standard of proof represents an attempt to instruct the fact-finder concerning the degree of confidence our society thinks he should have in the correctness of factual conclusions for a particular type of adjudication. Although the phrases 'preponderance of the evidence' and 'proof beyond a reasonable doubt' are quantitatively imprecise, they do communicate to the finder of fact different notions concerning the degree of confidence he is expected to have in the correctness of his factual conclusion'. $\quad$ Disponível em: <http://caselaw.lp.findlaw.com/scripts/getcase.pl?court=US\&vol=397\&invol=358>. Acesso em 12.6.2017.

${ }^{34}$ BELTRÁN, Jordi Ferrer. Prueba y Verdad en el derecho. Barcelona: Marcial Pons, 2005, p. 78. 
Revista Eletrônica de Direito Processual - REDP.

Rio de Janeiro. Ano 11. Volume 18. Número 2. Maio a Agosto de 2017

Periódico Quadrimestral da Pós-Graduação Stricto Sensu em Direito Processual da UERJ

Patrono: José Carlos Barbosa Moreira. ISSN 1982-7636. pp. 88-115

www.redp.uerj.br

decidir a lide pelas regras atinentes à distribuição do ônus da prova, que não mais dizem respeito à persuasão racional, pois, quando aplicadas, não há persuasão, mas, sim, aplicação do critério legal.

A definição do modelo de constatação a ser utilizado é estabelecida de acordo com os ditames de determinado ordenamento jurídico e os valores a ele subjacentes ${ }^{35}$, exigindose como corolário do princípio democrático prévia indicação, no momento do julgamento, sobre qual será o standard de prova adotado. ${ }^{36} \mathrm{O}$ âmago da questão, portanto, consiste nos princípios que orientam a distribuição dos riscos de erro na solução das questões fáticas no âmbito de determinado processo. Via de regra ${ }^{37}$, é possível distinguir, em ordem crescente de grau de probabilidade, três modelos principais de constatação, quais sejam: "preponderância de provas", "prova clara e convincente" e "prova além da dúvida razoável”. Ao processo civil, como regra geral, aplica-se o standard da "preponderância de provas" e ao processo penal o standard da "prova além da dúvida razoável" 38 _39.

$O$ standard da "prova clara e convincente" tem natureza intermediária entre os outros dois standards mencionados, e representa a situação em que os fatos são altamente prováveis. ${ }^{40}$ Esse modelo de constatação incide sobre os processos civis especiais, ou seja, aqueles que "envolvem um conflito de valores que em muito ultrapassa a simples dimensão patrimonial". ${ }^{41}$ São ações nas quais o bem jurídico é de tal forma relevante que exige um standard que vá além da mera preponderância de provas, como por exemplo, nas ações de família, mas o quantum de prova exigido para uma parte e outra permanece o mesmo.

\footnotetext{
35 TARUFFO, Michele. Tres observaciones sobre 'por qué un estándar de prueba subjetivo y ambiguo no es un estándar', de Larry Laudan. In: Doxa: Cuadernos de filosofía del derecho, nº 28 (2005), p. 119 .

${ }^{36}$ REICHELT, Luis Alberto. A Prova no Direito Processual Civil, op. cit., pp. 217 e 218.

${ }^{37}$ Existem outros parâmetros de constatação além dos citados nesse estudo. José Paulo Baltazar Júnior (In: KNIJNIK, Danilo (coord.) Prova Judiciária. Estudos sobre o novo direito probatório. Porto Alegre: Livraria do Advogado, 2007, pp. 158-159), exemplifica alguns deles, tais como, o da "mínima atividade probatória" do Tribunal Constitucional espanhol e o do "alto grau de verossimilhança sem dúvidas concretas", de construção jurisprudencial germânica.

${ }^{38}$ KNIJNIK, Danilo. A prova nos juízos cível, penal e tributário. Rio de Janeiro: Forense, 2007, p. 37.

${ }^{39}$ Em razão de esse estudo ter como objeto principal os standards de prova no âmbito do processo civil, consideramos como relevantes para o deslinde do tema somente os apontamentos mais detalhados em relação aos standards nesse âmbito.

40 BENNETT, Bryant M. Clear and Convincing Proof: Appellate Review. California Law Review, v. 32 ,

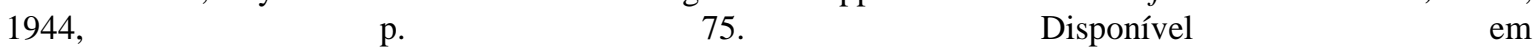
<http://scholarship.law.berkeley.edu/cgi/viewcontent.cgi?article=3624\&context=californialawreview > Acesso em 1.3.2017.

${ }^{41}$ KNIJNIK, Danilo, op. cit., p. 170.
} 
Revista Eletrônica de Direito Processual - REDP.

Rio de Janeiro. Ano 11. Volume 18. Número 2. Maio a Agosto de 2017

Periódico Quadrimestral da Pós-Graduação Stricto Sensu em Direito Processual da UERJ

Patrono: José Carlos Barbosa Moreira. ISSN 1982-7636. pp. 88-115

www.redp.uerj.br

Já nos processos civis de índole punitiva, em que a sanção do demandado tem reflexos semelhantes à sanção penal, haverá a modificação dos parâmetros de limitação do julgamento fático aplicados tradicionalmente ao âmbito do processo civil, não apenas pela relevância do bem jurídico em tela, mas também pelo desequilíbrio inerente a esse tipo de relação jurídica processual civil, a qual se aproxima, em suas características, da relação processual penal. ${ }^{42}$ Ademais, em virtude dessas peculiaridades, haverá nesses casos não somente uma alteração do standard de prova como também uma aplicação diversa dos ônus de prova, atribuindo-se unilateralmente o ônus de provar ao autor que está exigindo a aplicação da referida sanção.

Ressalte-se que há diferença entre a limitação probatória ao julgamento da questão fática exercida pelos modelos de constatação e aquela exercida pelos ônus de prova. ${ }^{43}$ Isso se dá em razão de os standards indicarem o grau de convencimento para que o juiz considere a existência ou não de determinado fato, incidindo, portanto, sobre a suficiência do convencimento judicial. Por outro lado, se as provas não forem consideradas suficientes para atingir o módulo de constatação elencado, o juiz não mais poderá se utilizar daquele conjunto probatório para tomar sua decisão. Em consequência disso, serão aplicadas as regras de distribuição dos ônus probatórios, as quais, nesse momento, já incidirão sobre a falta de convencimento judicial e não mais no âmbito da persuasão racional; nesse caso, estar-se-á diante da aplicação de um critério legal. ${ }^{44}$

A incidência das regras sobre o ônus probatório diminui ou aumenta conforme o grau de confirmação (standard) exigido para a prova de determinado fato. Se o módulo de

\footnotetext{
${ }^{42}$ Gustavo Badaró preleciona brilhantemente que "a razão de se exigir no processo penal um standard probatório mais elevado que no processo civil é de natureza política, e não simplesmente técnica. No processo penal, em razão da presunção de inocência, do ponto de vista probatório há um desequilíbrio estrutural entre as posições do acusado, a quem não incumbe nenhum ônus, e o acusador, sobre quem recai toda a carga probatória. Contudo, além de atribuir toda a carga da prova para a acusação, também se adota um standard de prova bastante elevado (...)”. (BADARÓ, Gustavo Henrique Righi Ivahy. Processo Penal. Rio de Janeiro, Campus, Elsevier, 2012, p. 298).

${ }^{43}$ ROSENBERG, Leo. La carga de la prueba, Traducción de la tercera edición de la obra alemana "Die Beweilast” (1951) de Ernesto Krotoschin, Buenos Aires: EJEA, 1956, § 6, pp. 56-57. Na versão castelhana: "La apreciación libre de la prueba y la carga de la prueba dominan dos terrenos que si bien están situados muy cerca uno del otro, están separados claramente por límites fijos. La apreciación libre de la prueba enseña al juez a obtener libremente la convicción de la verdad o falsedad de las afirmaciones sostenidas y discutidas, en el proceso, del conjunto de los debates, a base de sus conocimientos de la vida y de los hombres; la carga de la prueba le enseña a hallar la solución cuando la libre apreciación de la prueba no ha dado ningún resultado. El dominio de la carga de la prueba comienza allí donde termina el dominio de la libre apreciación de la prueba; si el juez atravesó este último sin poder encontrar la solución, la carga de la prueba le da lo que la libre apreciación de la prueba le negó".

${ }^{44}$ GUEDES, Clarissa Diniz. Persuasão Racional e Limitações Probatórias: enfoque comparativo entre os processos civil e penal, op. cit., p. 407.
} 
Revista Eletrônica de Direito Processual - REDP.

Rio de Janeiro. Ano 11. Volume 18. Número 2. Maio a Agosto de 2017

Periódico Quadrimestral da Pós-Graduação Stricto Sensu em Direito Processual da UERJ

Patrono: José Carlos Barbosa Moreira. ISSN 1982-7636. pp. 88-115

www.redp.uerj.br

constatação for mais equilibrado, o convencimento do juiz se guiará pela persuasão

racional acerca da tese prevalente; se for mais exigente, aplicar-se-ão, muito

frequentemente, as regras sobre o ônus da prova, diante da dificuldade de se alcançar o

suporte fático exigido.

A dificuldade de se aplicarem critérios exclusivamente quantitativos ao processo $^{45}$,

dada a insuficiência da chamada valoração probatória estatística ou matemática para solucionar os casos jurídicos específicos e o próprio reconhecimento do relativismo científico $^{46}$, conduzem à necessidade de amparar as decisões judiciais em algo mais. E, nesse ponto, a lógica do provável $^{47}$ também não é totalmente esclarecedora, porque não responde a perguntas acerca da suficiência dos elementos para decidir e da medida correta destes elementos. ${ }^{48}$

\footnotetext{
${ }^{45}$ Cf. para uma abordagem ampla do tema: TARUFFO, Michele. La prueba de los hechos. Tradução de Jordi Ferrer Beltrán. Madrid: Editorial Trotta, 2002, capítulo III, item 3, pp. 190-222; FERRER BELTRÁN, La valoración racional de la prueba. Madrid/Barcelona/Buenos Aires: Marcial Pons, 2007, segunda Parte, Capítulo 2, item 2.2.2, pp. 96-107; STELLA, Federico, Giustizia e modernità. La protezione dell'innocente e la tutela delle vittime, Terza edizione. Milano: Giuffrè, 2003, p. 53 e ss. Entre as perplexidades decorrentes da utilização, pura e simples, da prova estatística podem-se citar as seguintes: a) As regras de probabilidade objetiva estão dissociadas dos elementos concretos de prova, i.e., do caso concreto; b) Tais regras dependem da existência de bases estatísticas sobre a frequência geral dos fenômenos. Ainda, mesmo quando se utilizam critérios que levam em conta a credibilidade dos elementos de prova (teorias probabilísticas subjetivistas), estas teorias incorrem no risco de atribuírem um valor inicial equivocado aos elementos probatórios, já que não existem critérios seguros de atribuição de valor para o material probatório. Em suma, tais teorias subjetivistas apenas propiciam maior clareza de raciocínio na análise dos elementos disponíveis, mas têm como pressuposto valorações feitas a partir de critérios subjetivos. Em conclusão, o entendimento que prevalece é o de que a possibilidade de se empregarem dados estatísticos para a prova de fatos singulares é possível apenas em casos muito particulares, e somente na presença de condições específicas de validade do cálculo estatístico e de referibilidade deste ao caso concreto (neste sentido: TARUFFO, Michele. La valutazione delle prove. In: La prova nel processo civile. Milano: Giuffrè, 2012, capítulo IV, pp. 230).

${ }^{46} C f$. STELLA, Federico. Giustizia e modernità. La protezione dell'innocente e la tutela delle vitime, op. cit., p. 36. Ainda, sobre a dificuldade de se definir o progresso científico, confira-se a abordagem de LAUDAN, Larry. Scienza e relativismo. Controversie chiave in filosofia della scienza. Roma: Armando, 1997, pp. 17 e ss.

${ }^{47}$ Referimo-nos aqui à probabilidade lógica, baconiana, defendida por Jonathan Cohen (The probable and the provable. Oxford: Oxford University Press, 1977) e considerada muito útil por Michele Taruffo (La prueba de los hechos, Capítulo III, item 4.1, op. cit., p. 226). Essa concepção não escapa do método utilizado na avaliação da prova indiciária. De acordo com ela, o problema fundamental consiste na conexão lógica entre a prova e a hipótese de fato. É a partir desta conexão que se determina a gradação do amparo inferencial correspondente à hipótese a ser provada. Obviamente, quanto mais elementos convergentes para a mesma conclusão, maior será a probabilidade desta hipótese. Os problemas apresentados nas situações probatórias complexas se resolvem a partir desta estrutura, articulando-se e combinando-se as inferências para analisar o grau 'final' de probabilidade que os elementos de prova atribuem às diversas hipóteses.

48 "Também a regra jurídica de eleição do grau de confirmação é fruto de uma valoração racional; mas se trata de uma racionalidade diversa daquela própria da probabilidade lógica: mais que de racionalidade, deveríamos talvez falar de razoabilidade, de razoável aceitabilidade: é esta racionalidade - razoabilidade que exige [no processo penal] a prova no nível máximo, como prova que supera qualquer dúvida razoável”. ( $C f$. STELLA, Federico. Giustizia e modernità. La protezione dell'innocente e la tutela delle vitime, op. cit., p. 57. Tradução livre). Convergentemente, Carlo Zaza (Il ragionevole dubbio nella logica della prova penale.
} 
Revista Eletrônica de Direito Processual - REDP.

Rio de Janeiro. Ano 11. Volume 18. Número 2. Maio a Agosto de 2017

Periódico Quadrimestral da Pós-Graduação Stricto Sensu em Direito Processual da UERJ

Patrono: José Carlos Barbosa Moreira. ISSN 1982-7636. pp. 88-115

www.redp.uerj.br

Como se vê, são necessários, além de critérios lógico-racionais, critérios jurídicos para permitir que o juiz chegue a uma decisão justa. Daí emergem, portanto, os standards probatórios ou modelos de constatação exigidos para a escolha de determinadas hipóteses fáticas, bem como os critérios residuais consubstanciados nas regras sobre os ônus probatórios.

Cumpre ressaltar que, essas regras de julgamento são subsidiárias à busca da verdade, eis que a solução de mérito idealizada pelos processos civil e penal consiste numa sentença amparada na apuração completa dos fatos, sem objeções de qualquer ordem. Porém, como a verdade só pode ser alcançada na medida do que seja contextualmente possível, estes parâmetros estabelecem como deve o juiz decidir em situações em que: a) a verdade possível e aceitável não corresponda ao ideal de confirmação máxima e unívoca pelos elementos probatórios ou b) a verdade possível ou aceitável não tenha sido sequer alcançada.

\section{Breves considerações sobre a responsabilidade civil do médico}

A responsabilidade civil médica pode ser analisada a partir de dois enfoques ${ }^{49}$ : a responsabilidade do médico prestador de serviços enquanto profissional liberal e a responsabilidade médica em virtude da prestação de serviços empresariais pelos hospitais, laboratórios etc. Por questões metodológicas, esse tema tão complexo ${ }^{50}$ será aqui examinado apenas sob o ângulo do profissional médico.

Quanto à natureza jurídica da responsabilidade médica, entendemos, em consonância com Gustavo Tepedino, que se trata de um contrato sui generis e não de mera prestação de serviços, pois pelo médico não é devida somente a prestação de serviços

Milano: Giuffrè, 2008, pp. 12 e ss.) assinala a necessidade de que o livre convencimento seja permeado por critérios valorativos, dentre os quais sobressai, no processo penal, o critério da prova "além da dúvida razoável".

${ }^{49}$ CAVALIERI FILHO, Sergio. Programa de responsabilidade civil. $12^{\circ}$ ed. São Paulo: Atlas, 2015, p.472.

${ }^{50}$ A esse respeito: "O desafio maior dos operadores do Direito nessa espécie de demanda é operacionalizar um juízo valorativo que tem como substrato de atuação a conduta profissional do médico no caso concreto. A questão é tormentosa, porque envolve necessariamente uma análise apurada do comportamento profissional do médico e os efeitos daí decorrentes à luz da ciência médica, bem como o fator reacional de cada paciente diante do tratamento ministrado". (MELISO RODRIGUES, Alessandro Carlo. Responsabilidade civil médica: distribuição do ônus da prova e a teoria da carga probatória dinâmica. Disponível em: <http://www2.senado.leg.br/bdsf/bitstream/handle/id/507416/001017707.pdf? sequence=1>. Acesso em 13.2.2017). 
Revista Eletrônica de Direito Processual - REDP.

Rio de Janeiro. Ano 11. Volume 18. Número 2. Maio a Agosto de 2017

Periódico Quadrimestral da Pós-Graduação Stricto Sensu em Direito Processual da UERJ

Patrono: José Carlos Barbosa Moreira. ISSN 1982-7636. pp. 88-115

www.redp.uerj.br

mediante remuneração, mas também a atuação em consonância com os deveres médicos de extensão extrapatrimonial, próprios da relação médico-paciente. ${ }^{51}$

O médico é profissional liberal e a ele se aplicam as disposições do Código de Defesa do Consumidor ${ }^{52}$, que dispõe ser a responsabilidade dos profissionais liberais apurada mediante a verificação de culpa, sendo a responsabilidade, então, subjetiva. ${ }^{53}$

Os pressupostos da responsabilidade civil do médico são a existência de uma conduta voluntária, o dano injusto sofrido pela vítima, a relação de causalidade entre o dano e a ação do agente e o fator de atribuição da responsabilidade pelo dano ao agente, de natureza subjetiva (culpa ou dolo). ${ }^{54}$

Compete ao paciente lesado provar todas as alegações acerca dos fatos ensejadores do dever de indenizar, quais sejam: fato, ilicitude, culpabilidade dano e nexo de causalidade. Porém, “esse encargo é penoso e, muitas vezes, conduz à improcedência do pedido". ${ }^{55}$ Diante disso, o art. $6^{\circ}$, VIII, do Código de Defesa do Consumidor ${ }^{56}$ autoriza o juiz, segundo seu critério, a inverter o ônus de prova em favor do consumidor, condicionando tal modificação à presença da verossimilhança das alegações ou da hipossuficiência dele, devendo ser esta última entendida como técnica relacionada à posse de conhecimento ou informação. ${ }^{57}$

\footnotetext{
${ }^{51}$ TEPEDINO, Gustavo. Responsabilidade médica. Entrevista feita pelo Jornal Carta Forense em 1.12.2008. Disponível em: <http://www.cartaforense.com.br/conteudo/entrevistas/responsabilidade-medica/3129>. Acesso em 10.2.2017.

52 Assim dispõe o art. 14,§4 do Código de Defesa do Consumidor: "a responsabilidade pessoal dos profissionais liberais será apurada mediante a verificação de culpa". BRASIL. Lei $\mathrm{n}^{\circ}$ 8.078, de 11 de setembro de 1990. Código de Defesa do Consumidor. Disponível em: <http://www.planalto.gov.br/ccivil_03/leis/L8078.htm>. Acesso em: 02.08.2017.

${ }^{53}$ CAVALIERI FILHO, Sérgio. Programa de responsabilidade civil, op. cit., p. 473.

${ }^{54}$ AGUIAR JÚNIOR, Ruy Rosado de. Responsabilidade Civil do Médico. In: TEIXEIRA, Sálvio de Figueiredo (coordenador). Direito \& Medicina. Belo Horizonte: Del Rey, 2000, p.7.

${ }^{55}$ MELISO RODRIGUES, Alessandro Carlo. Responsabilidade civil médica: distribuição do ônus da prova e a teoria da carga probatória dinâmica, p. 252. Disponível em $\langle$ http://www2.senado.leg.br/bdsf/bitstream/handle/id/507416/001017707.pdf?sequence=1>. Acesso em 13.2.2017.

${ }^{56}$ Art. $6^{\circ}$, VIII do Código de Defesa do Consumidor: "a facilitação da defesa dos seus direitos, inclusive com a inversão do ônus da prova, a seu favor, no processo civil, quando, a critério do juiz, for verossímil a alegação ou quando for ele hipossuficiente, segundo as regras ordinárias de experiências". BRASIL. Lei n 8.078, de 11 de setembro de 1990. Código de Defesa do Consumidor. Disponível em <http://www.planalto.gov.br/ccivil_03/leis/L8078.htm>. Acesso em 2.8.2017.

${ }^{57}$ SICA, Heitor Mendonça. Questões velhas e novas sobre a inversão do ônus da prova (CDC, art. $6^{\circ}$, VIII). Revista de Processo. Vol. 146, 2007, p. 3-4.
} 
Revista Eletrônica de Direito Processual - REDP.

Rio de Janeiro. Ano 11. Volume 18. Número 2. Maio a Agosto de 2017

Periódico Quadrimestral da Pós-Graduação Stricto Sensu em Direito Processual da UERJ

Patrono: José Carlos Barbosa Moreira. ISSN 1982-7636. pp. 88-115

www.redp.uerj.br

A interpretação desse dispositivo à luz da teoria das cargas dinâmicas ${ }^{58}$ permite a

afirmação de que o consumidor não irá ficar totalmente liberado do encargo de provar o fato constitutivo do seu direito ou que essa inversão especial do Código de Defesa do

Consumidor vai acontecer automaticamente, pelo contrário, será ope judicis: a verossimilhança de um fato ou a hipossuficiência têm de ser constatadas pelo juiz a partir de uma decisão motivada, amparada em um conjunto probatório considerado suficiente para o juiz. ${ }^{59}$

\footnotetext{
${ }^{58}$ Referimo-nos à teoria das cargas dinâmicas probatórias, sistematizada pelo argentino Jorge W. Peyrano e fundamentada: a) no princípio da isonomia material no processo (paridade de armas); b) no critério da maior facilidade na produção da prova. A desigualdade - e, sobretudo, a desigualdade do ponto de vista probatório -, verificada no caso concreto, é pressuposto para a sua aplicação. Como explica Inês Lépori White, muitas vezes, este ideal de igualdade não se alcança quando as partes que são beneficiadas por ele não se encontram em igualdade de condições (WHITE, Inés Lépori. Cargas probatorias dinámicas. In: PEYRANO, Jorge W. (diretor) e WHITE, Inés Lépori (Coordinadora). Cargas probatorias dinámicas. Buenos Aires/ Santa Fé: Rubinzal-Culzoni, 2004, p. 65). Por isso, a aplicação da doutrina em exame pressupõe uma situação de desigualdade, na qual uma parte se posicione com dominante poder de apresentação de provas frente a outra que, sendo inferior, está impedida de produzi-la (BARBERIO, Sergio José. Cargas probatorias dinámicas ¿Qué debe probar el que no puede probar?. In: PEYRANO, Jorge W. (diretor) e WHITE, Inés Lépori (Coordinadora). Cargas probatorias dinámicas, op. cit., p. 105). Esta é uma teoria excepcional e residual (PEYRANO, Jorge W.. La doctrina de las cargas probatorias dinâmicas y la maquina de impedir en material jurídica. Cargas probatorias dinámicas, op. cit., p. 87), pela qual os ônus são atribuídos de forma concreta, conforme as características do caso. Ela ressalva a regra geral para flexibilizar, em hipóteses específicas, a distribuição estática, abstratamente prevista na lei. Por sua dinamicidade, tal teoria possibilita alterações que garantem a efetiva igualdade material no processo. Consoante explica Danilo Knijnik (A prova nos juízos cível, penal e tributário, op. cit., pp. 178-179): "O ônus estático e dinâmico parecem representar dois pontos de partida diversos, ao mesmo tempo válidos, na distribuição da prova. No primeiro, o critério é a natureza do fato a ser provado (constitutivo, modificativo, impeditivo ou extintivo), a despeito de quem se encontre em melhores condições de fazê-lo; no segundo, as possibilidades de acesso às provas relevantes ou algum comportamento que tenha inviabilizado a prova pela parte onerada. Contudo, a ideia de um ônus dinâmico não afasta, de per si, as regras legais a esse respeito fixadas pelo legislador: ao contrário, persistiria o enfoque estático, devendo os sujeitos processuais, na generalidade dos casos, examinar a sintaxe das normas e a natureza dos fatos alegados segundo sua posição funcional. A invocação do ônus dinâmico entraria em jogo quando a aplicação daquelas regras iniciais conduzisse a uma probatio diabolica, vindo a inutilizar a ação judiciária e o acesso útil ao Estado-jurisdição". Quanto à utilização da teoria das cargas dinâmicas na jurisprudência, ver: TJRS. Agravo n ${ }^{\circ}$ 70064340987, 10a Câm. Cív., Rel, Des. Jorge Alberto Schreiner Pestana, j. 30.4.2015. Disponível em < http://www.tjrs.jus.br/site/>. Acesso em 4.6.2017.

59 THEODORO JR., Humberto. Curso de Direito Processual Civil: teoria geral do direito processual civil, processo de conhecimento e procedimento comum. V.1. 57 ed. Rio de Janeiro: Forense, 2016, p. 913. No mesmo sentido, LOURENÇO, Haroldo. Teoria dinâmica do ônus da prova no novo CPC. Rio de Janeiro: Forense; São Paulo: Método, 2015, p. 60. A respeito da possibilidade de inversão ope judicis, Eduardo Cambi enfatiza a desnecessidade de previsão legal para sua realização: "a dimensão objetiva do direito fundamental à tutela jurisdicional adequada vincula o juiz que pode, diante das circunstâncias presentes no caso concreto, não ignorando o ônus diabólico criado a uma das partes, mesmo sem previsão legal, distribuir, mediante critérios racionais e sempre justificados, as cargas dinâmicas das provas entre os litigantes". CAMBI, Eduardo. Teoria das cargas probatórias dinâmicas (distribuição dinâmica do ônus da prova) exegese do art. $373, \S \S 1^{\circ}$ e $2^{\circ}$ do NCPC. In: DIDIER JR., Fredie (coord.); MACEDO, Lucas Buril de; PEIXOTO, Ravi; FREIRE, Alexandre (org). Coleção novo CPC: Doutrina selecionada: processo de conhecimento - provas. V.3. $2^{\circ}$ ed. Salvador: Jus Podivm, 2016, p. 540.
} 
Revista Eletrônica de Direito Processual - REDP.

Rio de Janeiro. Ano 11. Volume 18. Número 2. Maio a Agosto de 2017

Periódico Quadrimestral da Pós-Graduação Stricto Sensu em Direito Processual da UERJ

Patrono: José Carlos Barbosa Moreira. ISSN 1982-7636. pp. 88-115

www.redp.uerj.br

Especificamente quanto à culpa, esta é conceituada, em geral, como uma conduta voluntária contrária ao dever de cuidado imposto pelo Direito, gerando a produção de um evento danoso que é involuntário, embora previsto ou previsível. ${ }^{60}$ A cláusula geral de responsabilidade subjetiva está prevista no art. 927 do Código Civil de 2002, que deverá ser apreciado em conjunto com os art. 186 e 187 do mesmo diploma, onde o significado do ato ilícito está definido. ${ }^{61}$

Insta ressaltar que o conceito jurídico de culpa está sofreu evolução, não mais sendo compreendido apenas sob sua concepção puramente subjetiva ou psicológica, mas sendo também analisado sob o aspecto da culpa normativa, proposta pelos irmãos Mazeaud ${ }^{62}$. Sob esse enfoque, a culpa é entendida como "erro de conduta", apreciada em abstrato comparativamente com um modelo geral de conhecimento. Logo, para que seja apurado se o agente causador do dano agiu culposamente, necessário se faz comparar o seu comportamento com aquele que seria o adequado a um homem médio, padrão. ${ }^{63}{ }^{64}$

\subsection{A prova da culpa do médico sob a ótica dos standards probatórios}

A necessidade de maior ou menor confirmação das alegações feitas no processo a respeito de determinado fato está diretamente relacionada não somente à proteção conferida ao bem jurídico envolvido no debate processual, mas também a outros fatores, tais como: a evolução tecnológica, o acesso à prova, as opções de estado, opções de caráter cultural, moral etc. No caso da responsabilidade civil médica, a complexidade é um

\footnotetext{
${ }^{60}$ CAVALIERI FILHO, Sergio. Programa de Responsabilidade Civil, op. cit., p. 51.

${ }^{61}$ Código Civil de 2002. Art. 927: "aquele que por ato ilícito (arts. 186 e 187) causar dano a outrem, fica obrigado a repará-lo”. Art. 186: “aquele que por ação ou omissão voluntária, negligência ou imprudência, violar direito e causar dano a outrem, ainda que exclusivamente moral, comete ato ilícito".

62 SCHREIBER, Anderson. Novos paradigmas da responsabilidade civil: da erosão dos filtros da reparação à diluição dos danos. $2^{\mathrm{a}} \mathrm{ed}$. São Paulo: Atlas 2009, pp. 35- 43.

63 “(...) Através da nova concepção [culpa normativa], existirão tantos modelos de diligência quantos forem os tipos de conduta (profissional, desportiva, na direção de veículos etc.) presentes no contato humano, de modo que os parâmetros, entre os tipos, serão variáveis (e diz-se que foram 'subjetivados' ou relativizados). Isto é o que permite que se estabeleçam padrões de conduta que exigirão do agente um comportamento judicioso, o qual variará em cada situação, consideradas sua profissão e demais circunstâncias pessoais". (MORAES, Maria Celina Bodin de. Danos à pessoa humana: uma leitura civil constitucional dos danos morais. Rio de Janeiro: Renovar, 2003, p. 213).

64 " $\mathrm{Na}$ construção de tais modelos, as cortes não se têm baseado tão somente na consciência judicial, mas se socorrido, saudavelmente de parâmetros externos, buscando recursos na sociedade para formar o padrão de conduta, valendo-se de códigos de conduta especializados, oitiva de assistentes judiciais especializados, diretrizes emitidas por associações profissionais, etc.'. (SCHREIBER, Anderson. op. cit, p. 41-42).
} 
Revista Eletrônica de Direito Processual - REDP.

Rio de Janeiro. Ano 11. Volume 18. Número 2. Maio a Agosto de 2017

Periódico Quadrimestral da Pós-Graduação Stricto Sensu em Direito Processual da UERJ

Patrono: José Carlos Barbosa Moreira. ISSN 1982-7636. pp. 88-115

www.redp.uerj.br

elemento relevantíssimo para que seja compreendida a necessidade de incidir um standard mais elevado nesse processo. ${ }^{65}{ }^{66}$

Com efeito, o próprio nexo de causalidade entre a conduta médica e eventual dano já é, por si, extremamente complexo. E, embora não seja esse o alvo de nossa pesquisa, não se pode deixar de registrar que a demonstração do nexo causal é alvo de constantes debates em tema de responsabilidade civil (de modo geral, e não exclusivamente quanto às condutas médicas). Merece destaque, quanto ao ponto, a distinção de Benito Frosini quanto: a) aos standards adotados pela ciência (v.g., pelas ciências médicas e biológicas) para considerar provada a relação de causa e efeito; e b) aos standards probatórios utilizados em juízo, para a demonstração de fenômenos da mesma espécie, em casos específicos. Segundo o autor, a busca científica se ocupa somente de fenômenos e, a partir da frequência observada em pesquisas empíricas, estabelece um patamar mínimo para considerar provada determinada hipótese; trata-se da chamada causalidade genérica. Já no âmbito processual civil, tal probabilidade genérica deve ser associada à prova, em específico, da causalidade no caso individual, sob pena de não se atingir o modelo de constatação da preponderância, em seu sentido forte. ${ }^{67}$ Para fins de responsabilidade civil por erro médico, parece-nos, à primeira vista, que o standard adequado seria o da prova clara e convincente, tendo em vista os numerosos fatores que podem influir sobre os danos associados à saúde e bem-estar do paciente. ${ }^{68}$

Especificamente quanto à demonstração da culpa em tais casos de responsabilidade civil do médico, propõe-se a concepção de que o standard de prova adequado à comprovação da culpa pelo autor da ação de responsabilidade civil do médico é, também, o da prova clara e convincente. E assim deve ser porque, além da já aludida complexidade da

\footnotetext{
65، A complexidade inerente à medicina faz com que a responsabilidade médica seja obrigatoriamente definida de maneira eminentemente casuística, para melhor reconhecê-la ou afastá-la, o mais seguro critério é investigar o caso concreto". (DIAS, José de Aguiar. Da responsabilidade Civil - $6^{\circ}$ ed. - Rio de Janeiro: Forense, 1979, p. 295).

66 "As singularidades e controvérsias das ações de responsabilidade civil médica não são consequência da lei, do ordenamento, da doutrina ou jurisprudência, mas da própria medicina, que não é uma ciência exata". (GARCIA, André Almeida. Prova e responsabilidade civil médica. In: KNIJNIK, Danilo (coord.) Prova Judiciária. Estudos sobre o novo direito probatório. Porto Alegre: Livraria do Advogado, 2007, p. 44).

${ }^{67}$ FROSINI, Benito V. Le prove statistiche nel processo civile e nel processo penale. Milano: Giuffrè, 2002, pp. 38-40.

${ }^{68}$ Entendimento este que também é corroborado por um dos maiores expoentes do tema no Brasil, a saber, Danilo Knijnik, professor Doutor em Direito pela Universidade de São Paulo - USP (2002). Mestre em Direito pela Universidade Federal do Rio Grande do Sul - UFRGS (1997). Professor permanente do Programa de Pós - Graduação e Professor adjunto da faculdade de Direito da UFRGS.
} 
Revista Eletrônica de Direito Processual - REDP.

Rio de Janeiro. Ano 11. Volume 18. Número 2. Maio a Agosto de 2017

Periódico Quadrimestral da Pós-Graduação Stricto Sensu em Direito Processual da UERJ

Patrono: José Carlos Barbosa Moreira. ISSN 1982-7636. pp. 88-115

www.redp.uerj.br

demonstração da falta do dever de cuidado, tais demandas “envolvem um conflito de valores que em muito ultrapassa a simples dimensão patrimonial, gerando resultados graves para o demandado," 69

Dessa perspectiva não olvidou a jurisprudência do Tribunal de Justiça do Rio Grande do Sul em acordão ${ }^{70}$ que acolheu a tese de que é necessária a demonstração conclusiva de que houve defeito na prestação de serviço médico, mediante a utilização de provas cabais pelo apelante. Ademais, percebe-se, em julgados do TJRS ${ }^{71}$, a preocupação com a aplicação de sanções aos médicos advindas de sentenças que os responsabilizam civilmente sem levar em consideração que as questões tratadas nesses tipos de causas são tormentosas.

Segundo o relator de um desses julgados, ${ }^{72}$ há uma complexidade inerente à relação médico-paciente, em que existe a circunstância de uma pessoa fragilizada por uma doença, esperando naquele profissional o melhor atendimento. Associado a isso está o fato de que a medicina não é ciência exata, como, também, a circunstância de que o profissional médico não pode ser culpado por situações advindas da fraqueza da rede hospitalar brasileira. Por fim, arremata que, em virtude do maior acesso a informações advinda do desenvolvimento tecnológico, muitas vezes os cidadãos se utilizam das ações por erro médico na expectativa de obter lucro pelo infortúnio. ${ }^{73}$

Este último argumento está carregado de convicções pessoais e até preconceitos a respeito da postura dos indivíduos em geral, mas, de todo modo, não se pode deixar de considerar que o acesso irrestrito a todo tipo de informações pela rede mundial de computadores é um fator determinante para sugestionar e até persuadir as pessoas de fatos

\footnotetext{
${ }^{69}$ KNIJNIK, Danilo. A prova nos juízos cível, penal e tributário - Rio de Janeiro: Forense, 2007, p.170.

70 “'a prova produzida nos autos não é conclusiva acerca da comprovação da alegada imperícia médica, não se podendo, a rigor, pela obediência à aplicação do instituto da responsabilidade subjetiva, pelo menos em relação aos médicos suplicados, estabelecer-se qualquer juízo condenatório sem que a parte apelante tivesse feito prova cabal de que houve defeito na prestação do serviço médico com a imprecisa secção do nervo ótico e falta de perícia cirúrgica a ser apontada como a causa exclusiva do quadro de cegueira que infelizmente acometeu o apelante' . Apelação Cível n 70033135484, 6 Câm. Cív. Rel. Sylvio José Costa da Silva Tavares, j. 31.7.2014. Disponível em < http://www.tjrs.jus.br/site/>. Acesso em 4.6.2017.

${ }^{71}$ BRASIL. TJRS. Apelação Cível No 70067051995 ( No CNJ: 0390577-19.2015.8.21.7000). 9 Câm. Cív. Rel. Des. Carlos Eduardo Richinitti, j. 29.1.2016. Disponível em 〈http://www.tjrs.jus.br/site/〉. Acesso em 4.6.2017.

72 BRASIL. TJRS. Apel. Cív. no 70067051995, 9 Câm. Cível. Rel. Des. Carlos Eduardo Richinitti, j. 29.1.2016, pp. 20, 21 e 22. Disponível em <http://www.tjrs.jus.br/site/>. Acesso em 4.6.2017.

73 BRASIL. TJRS. Apelação Cível No 70067051995 (Nº CNJ: 0390577-19.2015.8.21.7000), 9 Câm. Cív. Rel. Des. Carlos Eduardo Richinitti, j. 29.1.2016, pp. 20, 21 e 22. Disponível em <http://www.tjrs.jus.br/site/>. Acesso em 4.6.2017.
} 
Revista Eletrônica de Direito Processual - REDP.

Rio de Janeiro. Ano 11. Volume 18. Número 2. Maio a Agosto de 2017

Periódico Quadrimestral da Pós-Graduação Stricto Sensu em Direito Processual da UERJ

Patrono: José Carlos Barbosa Moreira. ISSN 1982-7636. pp. 88-115

www.redp.uerj.br

que, muitas vezes, não são cientificamente comprovados ou, ainda, não representam a realidade específica vivenciada pelos interessados. Enfim, ainda que não se possa - e, de fato não se deve -, como fez o relator do referido julgado, presumir a má-fé da maioria das pessoas que ajuíza ações indenizatórias por supostos erros médicos, deve-se ponderar que, de um modo geral, as pessoas que são, de alguma forma, vitimadas por danos à própria saúde ou de seus familiares, tendem a estar mais vulneráveis ao sugestionamento advindo da multiplicidade de casos e informações disponíveis online.

Sérgio Cavalieri Filho observa que os Tribunais são severos na exigência da prova que demonstre a culpa do médico. ${ }^{74}$ Também para Ruy Rosado de Aguiar Júnior a culpa do médico tem que ser certa, mesmo que não seja grave, e o dano tem que ser certo e não hipotético. Ainda segundo ele, o juiz deve comparar a atuação do médico não com um padrão ideal, mas com a conduta devida por um profissional orientado conforme os padrões determinados pelo uso da ciência, considerando as mesmas circunstâncias em que estava o médico do caso em concreto. ${ }^{75}$ Esse posicionamento converge, de certa forma, com a ideia a que nos referimos quando mencionamos o standard probatório da causalidade, que é, justamente, de se associar o modelo de probabilidade genérico da ciência ao padrão de constatação exigido para o caso individual. Disso se dessume que não há, em regra, como preestabelecer genericamente condutas consideradas como práticas médicas culposas.

Veja-se, todavia, que o padrão de constatação da prova clara e convincente referese à prova da culpa, a ser feita pelo demandante. Trata-se da exigência de prova cabal, firme, no sentido de que o profissional teria faltado com o dever de cuidado. Se, todavia o juiz decidir pela inversão do ônus da prova a partir das necessidades do caso concreto, ao médico não será exigida a prova da sua culpa, mas da ausência dela (ou, ainda, da observância dos deveres de cuidado exigidos no caso específico). E, nesse ponto, tem se entendido que: se, por um lado, a existência da culpa deve ser provada de forma clara e convincente, por outro, de início, basta que a falta deste elemento seja minimamente comprovada para que não haja condenação.

\footnotetext{
${ }^{74}$ CAVALIERI FILHO, Sergio. Programa de responsabilidade civil, op. cit., p. 473.

75 AGUIAR JÚNIOR, Ruy Rosado de. Responsabilidade Civil do médico, p.13. Disponível em <http://www.ruyrosado.com.br/upload/site_producaointelectual/23.pdf>. Acesso em 14.4.2016.
} 
Revista Eletrônica de Direito Processual - REDP.

Rio de Janeiro. Ano 11. Volume 18. Número 2. Maio a Agosto de 2017

Periódico Quadrimestral da Pós-Graduação Stricto Sensu em Direito Processual da UERJ

Patrono: José Carlos Barbosa Moreira. ISSN 1982-7636. pp. 88-115

www.redp.uerj.br

Em outros termos, não são necessárias provas incontestáveis da inexistência de culpa. Tal raciocínio decorre do fato de que, nesse caso, a exigência de um standard mais elevado, como o da prova clara e convincente, somente se justifica na medida em que protege o profissional de sofrer injustamente as consequências de um erro judicial, pois, como outrora dito, a medicina é complexa, e não se pode penalizar um profissional pelo o que não estiver ao alcance dele. Ou seja, o standard da prova clara e convincente não tem a função de dificultar a defesa do demandado, mas impedir que ele sofra uma sanção com base em provas frágeis. ${ }^{76}$

Portanto, a flexibilização do ônus de prova permite que, como regra de conduta, ${ }^{77} \mathrm{o}$ réu se desincumba do ônus a partir de um modelo de constatação frágil, que pode, a nosso ver, ser classificado como o standard da prova mínima, alcançável até mesmo - mas não só - por prova indiciária. Enfatiza-se que a inversão do ônus de prova não se aplica ao elemento dano, da responsabilidade civil, já que o demandado não tem condição de provar a inexistência de dano sofrido pelo demandante, por ser esta prova de difícil acesso ao médico. Já o ônus de prova sob o prisma objetivo, regra de julgamento destinada ao juiz, servirá apenas como um critério residual ${ }^{78}$, sendo aplicado somente após a constatação de

\footnotetext{
${ }^{76}$ Já decidiu o TJRS que a ausência de culpa do médico será demonstrada mediante a verificação da ausência de conduta médica comprovadamente faltosa ou tecnicamente incorreta. (TJRS. Apel. Cív. no 70067051995. $9^{\circ}$ Câm. Cív. Rel. Des. Carlos Eduardo Richinitti, j. 29.1.2016. Disponível em < http://www.tjrs.jus.br/site/>. Acesso em 4.6.2017). No sentido de que a ausência de culpa será aferível mediante a simples comprovação de que o profissional agiu com prudência, diligência e perícia: "a obrigação assumida pelo médico é de meio e não de resultado. O objeto da obrigação não é a cura do paciente, e sim o emprego do tratamento adequado de acordo com o estágio atual da ciência, de forma cuidadosa e consciente, o que não verificou no caso dos autos.". (Apel. Cív. no 70067082263. $5^{\circ}$ Câm. Cív. Rel. des. Jorge Luiz Lopes do Canto, j. 30.3.2016, disponível em 〈http://www.tjrs.jus.br/site/>. Acesso em 4.6.2017. Não é diverso o entendimento do ilustre doutrinador Genival Veloso de França: “o médico, nas relações de consumo com seus clientes, não está obrigado a um resultado, pois entre eles existe um contrato de meios e não de fins. Seu compromisso é utilizar todos os meios e esgotar as diligências ordinariamente exercidas. Em suma: usar de prudência e diligenciar normalmente a prestação do serviço. Haverá inadimplência se a atividade for exercida de forma irregular, atípica ou imprudente, e, se na prestação do serviço venha ocorrer um acidente de consumo, o médico terá sua responsabilidade civil apurada dentro dos limites da má prática". FRANÇA, Genival Veloso de. Direito médico. 14. ed. rev. e atual. - Rio de Janeiro: Forense, 2017, p.97.

77 Enfatizando o aspecto subjetivo do ônus da prova, diz Arruda Alvim que: "o ônus é, por natureza, eminentemente subjetivo e relacionado com o agir ou com o não agir bem ou mal sucedido de um litigante" (Manual de direito processual civil, 17ª ed., São Paulo: RT, 2017, pp. 843). No mesmo sentido: BADARÓ, Gustavo Henrique Righi Ivahi. Do ônus da prova no processo penal, São Paulo: RT, 2003, Capítulo III, item 3.9, p. 182; LOPES, João Batista. O ônus da prova. In: MENDES, Gilmar Ferreira (coord); STOCO, Rui (coord.). Doutrinas Essenciais de direito civil. Vol. V. São Paulo: RT, 2011, p. 1035 e ss.; YARSHELL, Flávio Luiz. Antecipação da prova sem o requisito da urgência e direito autônomo à prova. São Paulo: Malheiros, 2009, pp. 46-53; CAMBI, Eduardo. A prova civil: admissibilidade e relevância. São Paulo: RT, 2006, pp. 22-232; BUZAID, Alfredo. Do ônus da prova. Revista de Direito Processual Civil, vol. 4, São Paulo: Saraiva,1964, pp. 16 e ss..).

${ }^{78}$ ALVIM, Arruda. Novo Contencioso Cível no CPC/2015. São Paulo: RT, 2016, p. 248.
} 
Revista Eletrônica de Direito Processual - REDP.

Rio de Janeiro. Ano 11. Volume 18. Número 2. Maio a Agosto de 2017

Periódico Quadrimestral da Pós-Graduação Stricto Sensu em Direito Processual da UERJ

Patrono: José Carlos Barbosa Moreira. ISSN 1982-7636. pp. 88-115

www.redp.uerj.br

que não foi atingido o grau de suficiência de provas determinado previamente. Isso significa que o conjunto probatório apto a ensejar ou não a responsabilização do médico será definido mais a partir do modelo de constatação do que nas regras de distribuição do ônus de prova. ${ }^{79}$

Cumpre justificar que, a respeito da prova da culpa pelo demandante, não seria possível optar pelo standard da preponderância de provas aplicado ao processo civil em geral, pois a prova preponderante representa apenas um grau mínimo de convicção - mera prevalência de determinadas provas em relação a outras - o que não se afigura compatível com a complexidade desse tipo de demanda e, mais especificamente, com a natureza multifatorial desse elemento de responsabilização.

Ademais, deve-se ter em conta que a conclusão fática definidora da solução dada à lide é apta a gerar efeitos muito prejudiciais a um dos litigantes - o profissional médico - 80 e, também, ao devido exercício desta profissão. Trata-se, portanto, de uma opção política esboçada na jurisprudência, no sentido de valorizar o exercício da profissão, responsabilizando o médico, apenas e tão somente, diante da prova cabal da culpa no exercício de seu mister.

\section{Conclusão}

O estudo dos standards probatórios permite verificar sua importância no âmbito da consecução dos objetivos da prova tanto na perspectiva demonstrativa como persuasiva, por serem tais modelos mais um parâmetro de racionalidade para as decisões judiciais sobre os fatos. Nessa medida, nada obstante a fluidez dos modelos de constatação, a adoção e explicitação destes na decisão judicial contribuem para que a análise dos fatos debatidos em juízo não se afaste da realidade fenomênica nem dos argumentos trazidos a juízo pelas partes.

\footnotetext{
${ }^{79}$ GUEDES, Clarissa Diniz. Op. cit., p. 412.

80 (...) A escolha do standard a ser aplicado em um caso particular, deve, em um mundo racional, refletir a avaliação social comparativa do efeito prejudicial de cada um. Quando alguém faz essa avaliação, o motivo para se escolher diferentes standards de prova no processo civil, oposto ao litígio criminal, se torna evidente. Em uma petição civil comum, em que o objetivo é indenização, nós não consideramos essa petição mais grave pela possibilidade de um veredito errôneo em favor do réu ao invés do autor. Logo, o standard da preponderância parece ser o adequado, por, como anteriormente explicado, simplesmente exigir que o julgador do fato "'acredite que a existência do fato é mais provável do que sua não existência"' (...) (US SUPREME COURT. In Re Winship 397 US 358, No 778, decided in March 31, 1970. Tradução livre. Disponível em: <https://supreme.justia.com/cases/federal/us/397/358/case.html>. Acesso em 14.6.2016).
} 
Revista Eletrônica de Direito Processual - REDP.

Rio de Janeiro. Ano 11. Volume 18. Número 2. Maio a Agosto de 2017

Periódico Quadrimestral da Pós-Graduação Stricto Sensu em Direito Processual da UERJ

Patrono: José Carlos Barbosa Moreira. ISSN 1982-7636. pp. 88-115

www.redp.uerj.br

Por outro lado, a existência de tais standards desvenda a impossibilidade de o juízo

fático realizado pelo órgão jurisdicional alcançar plenamente a verdade objetiva. Daí falarse na necessidade de distribuição de riscos de erros no julgamento. Tal distribuição leva em conta critérios jurídicos (princípios constitucionais, como a presunção da inocência, no processo penal; natureza do bem jurídico em jogo etc.) e não-jurídicos (v.g., maior dificuldade ou facilidade de apuração fática por determinadas ciências ).

Trata-se de critérios de julgamento, residuais à própria distribuição do ônus da prova enquanto regra de conduta, já que se referem ao requisito/parâmetro mínimo para se reputar determinada hipótese fática como provada, incidindo sobre a formação do convencimento do juiz. A eleição de determinado standard de prova não configura uma situação ideal, em que, se satisfeito, terá sido alcançada a verdade absoluta a respeito de determinada hipótese fática, mas pelo contrário, os standards representam uma reação do sistema às possibilidades de erro em uma decisão fática. Por isso, como visto ao longo do trabalho, destinam-se a orientar o julgador quanto à suficiência de determinado conjunto probatório para que a comprovação de determinada hipótese fática possa ser considerada racionalmente aceitável, e, por conseguinte, propiciam o controle do juízo fático a partir do instante em que o julgador se vê diante da necessidade de uma motivação consubstanciada em um parâmetro lógico racional, previamente elencado.

Especificamente quanto ao tema da responsabilidade civil por erro médico, a análise doutrinária e o estudo de casos implementado conduziram à conclusão de que o demandante (paciente) deve provar a culpa do médico por meio de um standard de prova mais elevado: o standard da prova clara e convincente. Cogita-se, pois, da prova "cabal" ou daquela que demonstre de forma clara e convincente de que o médico não agiu conforme diligência esperada por qualquer outro profissional médico nas mesmas circunstâncias. Caso se inverta o ônus da prova, deve o médico demonstrar a ausência de sua culpa por meio de um standard de grau mínimo. Aceita-se, portanto, uma prova frágil da inexistência de culpa.

Por ser o grau ou modelo de constatação exigível para determinados fatos um critério de julgamento que estabelece previamente a distribuição de riscos de não se alcançar a verdade, fica evidenciada a opção política de se preservar o exercício da profissão médica, bem como a utilização de critérios relacionados ao próprio desenvolvimento e complexidade da ciência médica. 
Revista Eletrônica de Direito Processual - REDP.

Rio de Janeiro. Ano 11. Volume 18. Número 2. Maio a Agosto de 2017

Periódico Quadrimestral da Pós-Graduação Stricto Sensu em Direito Processual da UERJ

Patrono: José Carlos Barbosa Moreira. ISSN 1982-7636. pp. 88-115

www.redp.uerj.br

\section{REFERÊNCIAS BIBLIOGRÁFICAS:}

AGUIAR JÚNIOR, Ruy Rosado de. Responsabilidade Civil do Médico. In: TEIXEIRA, Sálvio de Figueiredo (coordenador). Direito \& Medicina. Belo Horizonte: Del Rey, 2000. ALVIM NETTO, José Manoel de Arruda. Manual de direito processual civil. $17^{\mathrm{a}}$ ed. São Paulo: RT, 2017.

Novo Contencioso Cível no CPC/2015. 16ª ed. São Paulo: RT, 2016.

BADARÓ, Gustavo Henrique Righi Ivahy. Processo Penal. Rio de Janeiro: Campus, Elsevier, 2012.

. Processo penal. $3^{\mathrm{a}}$ ed. São Paulo: RT, 2015.

Do ônus da prova no processo penal. São Paulo: RT, 2003.

BALTAZAR JUNIOR, José Paulo. Standards probatórios. In: KNIJNIK, Danilo (coord). Prova Judiciária: Estudos sobre o novo Direito Probatório. Porto Alegre: Livraria do Advogado, 2007.

BARBERIO, Sergio José. Cargas probatorias dinámicas ¿Qué debe probar el que no puede probar? In: PEYRANO, Jorge W. (diretor) e WHITE, Inés Lépori (Coord). Cargas probatorias dinámicas. Buenos Aires/ Santa Fé: Rubinzal-Culzoni, 2004.

BRASIL. Lei $\mathrm{n}^{\circ}$ 8.078, de 11 de setembro de 1990. Código de Defesa do Consumidor. Disponível em <http://www.planalto.gov.br/ccivil_03/leis/L8078.htm>. Acesso em 2.8.2017.

BRASIL. TJRS. Apel. Cív. nº 70067051995. 9 Câmara Cível. Rel. Des. Carlos Eduardo Richinitti, j. 29.1.2016. Disponível em <http://www.tjrs.jus.br/site/>. Acesso em 4.6.2017. BRASIL. TJRS. Apel. Cív. no 70067082263. $5^{\circ}$ Câmara Cível. Rel. Des. Jorge Luiz Lopes do Canto, j. 30.3.2016. Disponível em < http://www.tjrs.jus.br/site/>. Acesso em 4.6.2017. BRASIL. TJRS. Apel. Cív. n 70033135484. $6^{\circ}$ Câmara Cível. Rel. Sylvio José Costa da Silva Tavares, j. 31.7.2014. Disponível em 〈http://www.tjrs.jus.br/site/>. Acesso em 4.6.2017.

BENNETT, Bryant M. Clear and Convincing Proof: Appellate Review. V. 32, California Law Review, 1944. Disponível em <http://scholarship.law.berkeley.edu/cgi/viewcontent. cgi? article $=3624 \&$ context $=$ californialawreview $>$. Acesso em 1.3.2017. 
Revista Eletrônica de Direito Processual - REDP.

Rio de Janeiro. Ano 11. Volume 18. Número 2. Maio a Agosto de 2017

Periódico Quadrimestral da Pós-Graduação Stricto Sensu em Direito Processual da UERJ

Patrono: José Carlos Barbosa Moreira. ISSN 1982-7636. pp. 88-115

www.redp.uerj.br

BUZAID, Alfredo. Do ônus da prova. Revista de Direito Processual Civil, vol. 4, São Paulo: Saraiva, 1964.

CAMBI, Eduardo. A prova civil: admissibilidade e relevância. São Paulo: RT, 2006.

Teoria das cargas probatórias dinâmicas (distribuição dinâmica do ônus da prova) - exegese do art. $373, \S \S 1^{\circ}$ e $2^{\circ}$ do NCPC. In: DIDIER JR., Fredie (coord); MACÊDO, Lucas Buril de; PEIXOTO, Ravi; FREIRE, Alexandre. Provas. Coleção novo CPC. Doutrina selecionada. $2^{a}$ ed. Salvador: Jus Podivm, 2016.

CAVALIERI FILHO, Sergio. Programa de responsabilidade civil. $12^{\circ}$ ed. São Paulo: Atlas, 2015.

CORDERO, Franco. In: Tre studi sulle prove penali. Milano: Giuffrè, 1963.

DEMARI, Lisandra. Juízo de relevância da prova. In: KNIJNIK, Danilo (coord.) Prova Judiciária. Estudos sobre o novo direito probatório. Porto Alegre: Livraria do Advogado, 2007.

DENTI, Vittorio. Cientificidad de la prueba y libre valoración del juez. Estudios e derecho probatorio. Trad. para o castelhano de Santiago Sentís Melendo e Tomás A. Banzhaf. Buenos Aires: EJEA, 1974.

DIAS, José de Aguiar. Da responsabilidade Civil. $6^{\circ}$ ed. Rio de Janeiro: Forense, 1979.

DIDIER JR., Fredie; BRAGA, Paula Sarno; OLIVEIRA, Rafael Alexandria de. Curso de Direito Processual Civil: teoria da prova, direito probatório, ações probatórias, decisão, precedente, coisa julgada e antecipação dos efeitos da tutela. V.2. 10 ${ }^{\mathrm{a}}$ ed. Salvador: Jus Podivm, 2015.

DOSI, Ettore. Sul principio del libero convincimento del giudice nel processo penale. Milano: Giuffrè, 1957.

FERRER BELTRAN, Jordi. A prova é liberdade, mas não tanto: uma teoria da prova quase-benthamiana. In: DIDIER JR., Fredie (coord); MACÊDO, Lucas Buril de; PEIXOTO, Ravi; FREIRE, Alexandre. Provas. Coleção novo CPC. Doutrina selecionada. $2^{\mathrm{a}}$ ed. Salvador: Jus Podivm, 2016.

Prova e verità nel diritto. Bologna: Società editrice il Mulino, 2004.

La valoración racional da la prueba. Madrid/ Barcelona/Buenos Aires: Marcial

Pons, 2007.

FERRAJOLI, Luigi. Direito e Razão. Teoria do Garantismo Penal, 4a ${ }^{\mathrm{a}}$ ed. rev. Trad. Ana Paula Zomer Sica e outros. São Paulo: RT, 2014. 
Revista Eletrônica de Direito Processual - REDP.

Rio de Janeiro. Ano 11. Volume 18. Número 2. Maio a Agosto de 2017

Periódico Quadrimestral da Pós-Graduação Stricto Sensu em Direito Processual da UERJ

Patrono: José Carlos Barbosa Moreira. ISSN 1982-7636. pp. 88-115

www.redp.uerj.br

FRANÇA, Genival Veloso de. Direito médico. 14ª ed. Rio de Janeiro: Forense, 2017.

FROSINI, Benito V. Le prove statistiche nel processo civile e nel processo penale. Milano: Giuffrè, 2002.

GARCIA, André Almeida. Prova e responsabilidade civil médica. In: KNIJNIK, Danilo (coord.) Prova Judiciária. Estudos sobre o novo direito probatório. Porto Alegre: Livraria do Advogado, 2007.

GRECO, Leonardo. O conceito de prova. Estudos de Direito Processual. Campos dos Goytacazes: Editora da Faculdade de Campos, 2005.

GUEDES, Clarissa Diniz. Persuasão racional e limitações probatórias: enfoque comparativo entre os processos civil e penal. Tese de doutorado, orientador: José Rogério Cruz e Tucci. São Paulo: USP, 2013.

; LEAL, Stela Tannure. O cerceamento do acesso à prova devido à confusão entre os planos de admissibilidade e valoração do material probatório. Revista de Processo, v. 240. Fev. 2015.

GUZMÁN, Nicolás. La verdad en el proceso penal. Una contribución a la epistemología jurídica. Buenos Aires: Editores del Puerto, 2006.

KNIJNIK, Danilo. A prova nos juízos cível, penal e tributário. Rio de Janeiro: Forense, 2007.

Os Standards do Convencimento Judicial: paradigmas para o seu possível controle. Disponível em: 〈http://www.abdpc.org.br/abdpc〉. Acesso em: 01/04/ 2017.

LAUDAN, Larry. Por qué un estándar de prueba subjetivo y ambiguo no es un estándar.

DOXA, Cuadernos de Filosofía del Derecho, 28 (2005).

. Scienza e relativismo. Controversie chiave in filosofia della scienza. Roma:

Armando, 1997

LESSONA, Carlo. Teoría general de prueba en derecho civil o exposición comparada de los principios de la prueba y sus diversas aplicaciones en Italia, Francia, Alemana etc., Madrid: Instituto Editorial Réus, 1957.

LOPES, João Batista. O ônus da prova. In: MENDES, Gilmar Ferreira (coord); STOCO, Rui (coord.). Doutrinas Essenciais de direito civil. Vol. V. São Paulo: RT, 2011.

LOURENÇO, Haroldo. Teoria dinâmica do ônus da prova no novo CPC. Rio de Janeiro: Forense; São Paulo: Método, 2015. 
Revista Eletrônica de Direito Processual - REDP.

Rio de Janeiro. Ano 11. Volume 18. Número 2. Maio a Agosto de 2017

Periódico Quadrimestral da Pós-Graduação Stricto Sensu em Direito Processual da UERJ

Patrono: José Carlos Barbosa Moreira. ISSN 1982-7636. pp. 88-115

www.redp.uerj.br

MARINONI, Luiz Guilherme; ARENHART, Sérgio Cruz; MITIDIERO, Daniel. Novo curso de processo civil: teoria do processo civil. V.1. São Paulo: RT, 2015.

MATTOS, Sérgio. O juiz é destinatário da prova: porta aberta para o arbítrio? In: MITIDIERO, Daniel e AMARAL, Guilherme Rizzo (Coord). Processo civil. Estudos em homenagem a Carlos Alberto Alvaro de Oliveira. São Paulo: Atlas, 2012.

MELISO RODRIGUES, Alessandro Carlo. Responsabilidade civil médica: distribuição do ônus da prova e a teoria da carga probatória dinâmica. Disponível em: <http://www2.senado.leg.br/bdsf/bitstream/handle/id/507416/001017707.pdf?sequence=1> .Acesso em: 13.2.2017.

MONICA, Giuseppe Della. La parabola del libero convincimento. In: GAITO, Alfredo. La prova penale. Volume Terzo (La valutazione della prova). Torino: UTET Giuridica, 2008. MORAES, Maria Celina Bodin de. Danos à pessoa humana: uma leitura civil constitucional dos danos morais. Rio de Janeiro: Renovar, 2003.

NIEVA FENOLL, Jordi. La valoración de la prueba. Madrid/Barcelona/Buenos Aires: Marcial Pons, 2010.

NOBILI, Massimo. Il principio del libero convincimento del giudice, Il principio del libero convincimento del giudice. Milano: Giuffrè, 1974.

PATTI, Salvatore. Libero Convincimento e valutazione delle prove, Rivista di diritto processuale. Ano XL, n. 3. Padova: CEDAM, 1985.

REICHELT, Luis Alberto. A Prova no Direito Processual Civil. Porto Alegre: Livraria do Advogado, 2009.

ROSENBERG, Leo. La carga de la prueba, Traducción de la tercera edición de la obra alemana "Die Beweilast" (1951) de Ernesto Krotoschin, Buenos Aires: EJEA, 1956.

SANTOS, Moacyr Amaral. Prova Judiciária no Cível e Comercial. V. 1. $5^{\text {a }}$ ed. São Paulo: Saraiva, 1983.

SCHREIBER, Anderson. Novos paradigmas da responsabilidade civil: da erosão dos filtros da reparação à diluição dos danos. $2^{\mathrm{a}}$ ed. São Paulo: Atlas 2009.

SENTÍS MELENDO, Santiago. La prueba. Buenos Aires, EJEA, 1978.

SICA, Heitor Mendonça. Questões velhas e novas sobre a inversão do ônus da prova (CDC, art. 6, VIII). Revista de Processo. v. 146, abr. 2007.

STELLA, Federico, Giustizia e modernità. La protezione dell'innocente e la tutela delle vittime. Terza edizione. Milano: Giuffrè, 2003. 
Revista Eletrônica de Direito Processual - REDP.

Rio de Janeiro. Ano 11. Volume 18. Número 2. Maio a Agosto de 2017

Periódico Quadrimestral da Pós-Graduação Stricto Sensu em Direito Processual da UERJ

Patrono: José Carlos Barbosa Moreira. ISSN 1982-7636. pp. 88-115

www.redp.uerj.br

TARUFFO, Michele. Apresentação. In: FERRER BELTRÁN, Jordi. Prueba y verdade em el derecho. 2 edición. Madrid/Barcelona: Marcial Pons, 2005.

La prueba de los hechos. Traducción de Jordi Ferrer Beltrán. Madrid: Editorial Trotta, 2002.

La prova dei fatti giuridici. Milano: Giuffrè 1992.

. La valutazione delle prove. In: La prova nel processo civile. Milano: Giuffrè, 2012.

Tres observaciones sobre 'por qué un estándar de prueba subjetivo y ambiguo no es un estándar', de Larry Laudan. In: Doxa: Cuadernos de filosofía del derecho, n, 28 (2005).

La valutazione delle prove. In: id. La prova nel processo civile. Milano: Giuffrè, 2012.

TEPEDINO, Gustavo. Responsabilidade médica. Entrevista feita pelo Jornal Carta Forense em 1.12.2008.

Disponível

em

<http://www.cartaforense.com.br/conteudo/entrevistas/responsabilidade-medica/3129>.

Acesso em 10.2.2017.

THEODORO JR., Humberto. Curso de Direito Processual Civil: teoria geral do direito processual civil, processo de conhecimento e procedimento comum. V.1. 57 ad. Rio de Janeiro: Forense, 2016.

UNITED STATES SUPREME COURT. In re Winship. No. 778. Decided: March 31, 1970: Rena K. Uviller for appellant and Stanley Buchsbaum for appellee. Mr. Justice Brennan delivered the opinion of the court. Disponível em <http://caselaw.lp.findlaw.com/scripts/getcase.pl?court=US\&vol=397\&invol=358>.

WHITE, Inês Lépori. Cargas probatorias dinámicas. In: PEYRANO, Jorge W. (diretor) e WHITE, Inés Lépori (Coord). Cargas probatorias dinámicas. Buenos Aires/ Santa Fé: Rubinzal-Culzoni, 2004.

YARSHELL, Flávio Luiz. Antecipação da prova sem o requisito da urgência e direito autônomo à prova. São Paulo: Malheiros, 2009.

ZAZA, Carlo. Il ragionevole dubbio nella logica della prova penale. Milano: Giuffrè, 2008. 